\title{
ARTICLE
}

\section{Revealing of biodiversity and antimicrobial effects of Artemisia asiatica endophytes}

\author{
Aruna Vigneshwari', Saruul Erdenebileg ${ }^{1}$, Kata Fujkin', Dezső Csupor³ ${ }^{3}$ Judit Hohmann³ \\ Tamás Papp ${ }^{1,2}$, Csaba Vágvölgyi' ${ }^{1}$, András Szekeres ${ }^{1 *}$ \\ 'Department of Microbiology, Faculty of Science and Informatics, University of Szeged, Szeged, Hungary \\ ${ }^{2}$ MTA-SZTE Fungal Pathogenicity Mechanisms Research Group, Hungarian Academy of Sciences - University of \\ Szeged, Szeged, Hungary \\ ${ }^{3}$ Department of Pharmacognosy, Faculty of Pharmacy, University of Szeged, Szeged, Hungary
}

\begin{abstract}
Endophytic fungi produce a plethora of secondary metabolites, which may open new avenues to study their applicability in pharmaceuticals. Therefore, the present study focuses on the fungal endophytic community of Artemisia asiatica. During our work, fungal endophytes were isolated from a medicinal plant, $A$. asiatica. The culturable endophytic fungi were identified using molecular techniques and biodiversity, richness and tissue specificity were examined. As these microorganisms have been generally identified as an abundant reservoir of novel antimicrobial compounds, the antimicrobial (i.e. antibacterial and antifungal) activities of the metabolites produced by the isolated fungi were studied. Numerous extracts containing the endophytic metabolites proved to be active against the applied test microorganisms including Gram-positive and Gramnegative bacteria, as well as yeasts and filamentous fungi, which can be examined in detail in the future and, based on the the chemical nature of these active metabolites, allow to discover novel bioactive metabolites.

Acta Biol Szeged 64(2):111-119 (2020)

\section{KEY WORDS}

antimicrobial effect Artemissia asiatica endophytic fungi fungal biodiversity

\section{ARTICLE INFORMATION}

Submitted

26 November 2020

Accepted

28 December 2020

*Corresponding author

E-mail: andras.j.szekeres@gmail.com
\end{abstract}

\section{Introduction}

Endophytic fungi can be defined as an ecological group of fungi colonizing the inner tissues of plants without any recognizable features of their presence (Wani et al. 2016). The plant's endophytic fungi spend their lifecycle colonizing inter- and/or intra-cellularly the healthy tissues of the host plants, without causing any apparent indication of disease.

For agriculture, pharmaceutical and food industry, plant-associated endophytic fungi have been observed as important and novel sources of natural bioactive products (Zhao et al. 2010; Yo and Ting 2017). Until now tens of thousands of natural products have been identified in the world, but still a vast number of unknown compounds are waiting for discovery and to be utilized for the benefits of mankind (Sarker 2012). The comprehensive review by Newman and Cragg (2016), provides detailed information about the natural compounds discovered between 1981-2014. Of the 1562 new chemical entities discovered in this period, $73 \%$ belongs to natural products and their derivatives and only $27 \%$ of the drugs were of synthetic origin. Furthermore, the increasing prevalence of new diseases results in the continuous need of exploiting natural products for drugs (Cragg and Newman 2013). Especially, the emergence of multidrug-resistant microbes increases the urge to find novel therapeutic leads (Talebi et al. 2019). Demain and Sanchez (2009) estimate that currently more than 1 million natural compounds have been isolated, from which $50-60 \%$ have plant and 5\% have microbial origins. In recent decades, endophytes have been recognized as a source of several bioactive compounds and are studied as potential sources of novel natural products for the health sector and for drug discovery (Jalgaonwala et al. 2011; Lam 2007; Strobel and Daisy 2003; Shukla et al. 2014; Vigneshwari et al. 2019). However, it could provide an important alternative to overcome the increasing levels of drugs resistance to various pathogenic microorganisms, only a few plant species have been investigated for their endophytic diversity and their bioactive secondary metabolites until now (Shukla et al. 2014).

The medicinal plants are potential sources of fungal endophytes producing novel bioactive compounds (Kaul et al. 2012), plant hormones (Khan et al. 2017; Turbat et al. 2020), and plant associated therapeutic metabolites (Huang et al. 2007; Vigneshwari et al. 2019). The plant genus Artemisia consists of around 400 species and these are one of the most important sources of medicinal compounds (Koul et al. 2018). Among the Artemisia species, $A$. 
annua is the best known due to its artemisinin content, which is an important antimalarial drug (Weathers et al. 2011). Liu et al. (2001) identified 14 fungal endophytes, which produced antagonistic compounds against four phytopathogens, in A. annua. Another study showed the bioactive potential of endophytic fungi isolated from $A$. annua, including Aspergillus sp. and Cephalosporium sp., which showed the highest antibacterial activity (Zhang et al. 2014).

A. asiatica Nakai is also the member of the Artemisia (mugwort) genus. This is a perennial plant and abundantly found in the northern temperate regions of Asia, Europe and North America. This species is widely known for its medicinal properties and their essential oil is commonly used in medicine and food products (Oh et al. 2005; Ryu et al. 1998; Ahuja et al. 2018). Characteristic secondary metabolites of $A$. asiatica include flavonoids, coumarins, terpenes, sesquiterpene lactones, monoterpenes, guaianolidem secoguianolide, lignans, phenylpropanoids and steroids (Hajdú et al. 2014). Despite the broad-spectrum bioactivity of $A$. asiatica, its endophytic fungal community and their bioactive compounds has not been investigated. Therefore, in our study, isolation and identification of endophytic fungi from $A$. asiatica were carried out and their biodiversity parameters were evaluated. Furthermore, antimicrobial activities of metabolites extracted using different organic solvents from both the ferment broth and the mycelia of the isolated endophytic fungi were also determined.

\section{Materials and Methods}

\section{Collection of $A$. asiatica samples and isolation of the endophytes}

The A. asiatica Nakai plants were provided by the Department of Pharmacognosy, University of Szeged (Szeged, Hungary). The samples were collected in 2016 and the plant specimens have been identified and authenticated by experts. Collected specimen was placed in a sealed plastic bag and was labelled with the number and date of collection and stored at $4{ }^{\circ} \mathrm{C}$ until processing.

Isolation of endophytic fungi from plant parts was done based on the method described by Gariyali (2013) with minor modifications. The plant materials were rinsed in running tap water to remove contaminations and the specimens were cut via a sterile blade into small segments of about 0.5 to $1 \mathrm{~cm}$ in length. The leaf and stem parts were separated, and these parts were examined for their fungal endophyte content. The plant segments were firstly surface sterilized by sequentially immersing the plant material in 70\% (60 sec) ethanol, washing with sterile distilled water and then, steeping in $0.01 \%(30 \mathrm{sec})$ mercuric chloride (VWR International, Hungary). Finally, the specimens were washed again 2-3 times with sterile distilled water and then dried on a sterile blotting paper. After the surface sterilisation, each segment was placed onto the surface of PDA medium (VWR International, Hungary) supplemented with $50 \mu \mathrm{g} / \mathrm{mL}$ ampicillin (Merck, Hungary) in a Petri dish. Then, the plates were incubated at $25^{\circ} \mathrm{C}$ and the growth of fungal colonies were checked daily for 5-10 days. Pure isolates were collected by picking up individual colonies from the plates and transferring them onto a fresh PDA medium, which were incubated at $25^{\circ} \mathrm{C}$ for 10 days. Each fungal culture was checked again for purity and transferred separately to PDA slants. These colonies were maintained at $4{ }^{\circ} \mathrm{C}$ and were deposited into the Szeged Microbiological Collection (SZMC, Hungary; http://www.wfcc.info/ccinfo/collection/by_id/987).

\section{Molecular identification of isolates}

For DNA isolation, fungal isolates were grown in PDB (VWR International, Hungary) at $25^{\circ} \mathrm{C}$ for 5 days. Isolation of the genomic DNA from the mycelia was performed using the E.Z.N.A. Fungal DNA Mini Kit (Omega Bio-tek, Norcross, USA) based on the manufacturer's instructions. The internal transcribed spacer (ITS) region of the rDNA was amplified using the primers ITS1 and ITS4 as described previously (White et al. 1990). Sequencing was performed commercially by BaseClear B.V. (Leiden, The Netherlands). Sequences were first analyzed by BLAST similarity search at the website of the National Center for Biotechnology Information (http://www.ncbi.nlm. nih.gov/BLAST) and the species were identified based on their identity values (>97\%).

\section{Screening of bioactive metabolite producing endophytic fungi}

\section{Secondary metabolite extraction}

Endophytic isolates were cultivated in $50 \mathrm{~mL}$ PDB medium at $25^{\circ} \mathrm{C}, 120 \mathrm{rpm}$ for 7 days. At the end of the incubation period mycelia was filtered through a cotton wool. The ferment broths were extracted three times sequentially with 50-50 mL of hexane, ethyl acetate and chloroform, respectively, and the extracts containing same solvents were pooled. The mycelial samples were overnight dried in an oven until constant weight and $25 \mathrm{~mL}$ distilled water was added to each. Then, the mixtures were sonicated for 20 min after the addition of an aliquot of liquid nitrogen to maintain the chilled condition. After that, the extraction of the aqueous samples was done three times with the mixture of $25 \mathrm{~mL}$ of chloroform and methanol (4:1, $\mathrm{V} / \mathrm{V})$. Both the ferment broth and the mycelial extracts were evaporated by a rotary evaporator (IKA HB10 basic, VWR International, Hungary) in vacuum at $30{ }^{\circ} \mathrm{C}$. The 
resulted four dry samples per each isolate were stored at $-20^{\circ} \mathrm{C}$ and resuspended in $1 \mathrm{~mL}$ of HPLC grade methanol (VWR International, Hungary) prior to use.

\section{Microdilution based antimicrobial assay}

To test the antibacterial effects of the metabolites, $400 \mu \mathrm{L}$ of the methanolic solution of all extracts were transferred into Eppendorf tubes and after the evaporation were dissolved in $1 \mathrm{~mL} \mathrm{10 \%} \mathrm{methanol.} \mathrm{These} \mathrm{solutions} \mathrm{were}$ tested against two Gram-negative bacteria, E. coli (SZMC 6271) and P. aeruoginosa (SZMC 23290), two Gram-positive bacteria, S. aureus (SZMC 14611) and B. subtilis (SZMC 0209) and two yeasts, C. albicans (SZMC 1533) and C. krusei (SZMC 1352) according to the M07-A10 CLSI guideline (Weinstein 2018), all of which were obtained from the SZMC, Szeged, Hungary. For the test, the suspensions of the microbes were prepared from overnight cultures, which were cultivated in Luria-Bertani broth (10 g tryptone, $5 \mathrm{~g}$ yeast extract and $5 \mathrm{~g} \mathrm{NaCl}$ in $1 \mathrm{~L}$ distilled water) and yeast extract peptone dextrose broth (20 g peptone, 10 g yeast extract and $20 \mathrm{~g}$ glucose in $1 \mathrm{~L}$ distilled water) for the bacteria and yeasts, respectively, at $37^{\circ} \mathrm{C}$. The concentrations of the suspensions were set to $4 \times 10^{5}$ cells/ $\mathrm{mL}$ with sterile media and $100 \mu \mathrm{L}$ of this suspension were transfered into the wells of 96 -well plates. Then, $100 \mu \mathrm{L}$ of the extract was added into each well, and the plates were then incubated for $24 \mathrm{~h}$ at $37^{\circ} \mathrm{C}$. The mixture of $100 \mu \mathrm{L}$ of ferment broth and $100 \mu \mathrm{L}$ of $10 \%$ methanol was used as the blank sample for background correction, while 100 $\mu \mathrm{L}$ of the microbial suspension supplemented with 100 $\mu \mathrm{L}$ of $10 \%$ methanol was applied as the negative control. The positive control contained ampicillin $(100 \mu \mathrm{g} / \mathrm{mL}$, Merck, Hungary) for bacteria and nystatin $(10 \mu \mathrm{g} / \mathrm{mL}$, Merck, Hungary) for yeasts. The inhibitory effects of the extracts were spectrophotometrically (SPECTROstar Nano, BMG LABTECH, Ordenberg, Germany) determined at $620 \mathrm{~nm}$ after incubation, and the inhibition rate was calculated as the percentage of the positive control after blank correction.

\section{Agar diffusion test}

To determine the potential antifungal activity of the fungal extracts against plant pathogenic fungi four holes with a diameter of $8 \mathrm{~mm}$ were bored into PDA plates, at the $2.5-\mathrm{cm}$ distances around the centre of the plate. Then precultured $\left(25^{\circ} \mathrm{C}, 7\right.$ days) Fusarium culmorum (SZMC 11039) and Rhizoctonia solani (SZMC 21048) strains were placed in the centre of plates with agar plugs and $100 \mu \mathrm{L}$ of the $10 \%$ methanolic extracts prepared for the microdilution assay were applied into the wells. As a solvent control, $10 \%$ methanol was used and a mycelial plug inoculated without any extracts was applied as a growing control. Antifungal activities of the samples were determined by

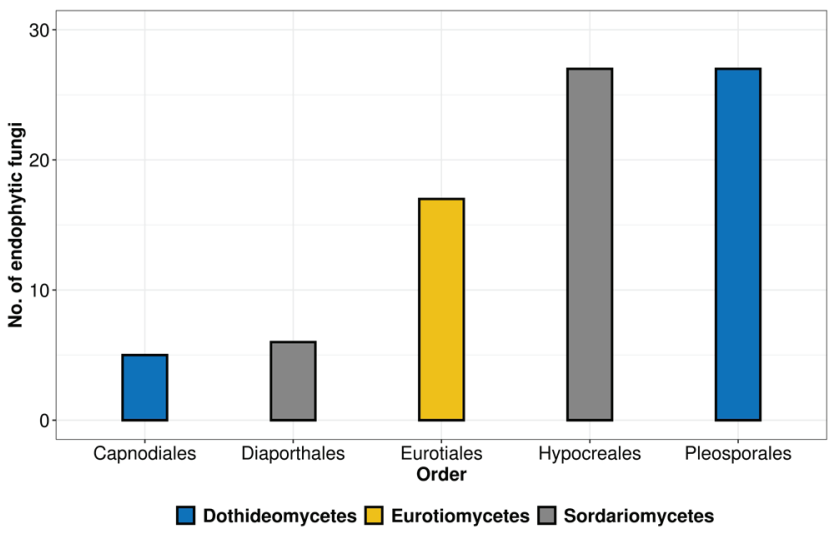

Figure 1. Distribution of endophytic fungi isolated from $A$. asiatica into classes and orders.

the detection of the inhibition zone.

\section{Biodiversity mapping of endophytic fungi of A. asiatica}

\section{Calculating isolation rate and diversity parameters}

The isolation rate of the endophytic fungi was calculated as the total number of tissue segments infected by fungi divided by the total number of tissue segments incubated (Kumar and Hyde 2004).

The diversity of endophytic fungi were evaluated using the Shannon-Weiner Index ( $\left.\mathrm{H}^{\prime}\right)$, Simpson's diversity index (1-D), evenness Index (J) and Margalef richness index (Hoffman et al. 2008; Suryanarayanand and Kumaresan 2000; Kusari et al. 2012). All the diversity indexes were calculated both plant wise and also tissue wise.

\section{Statistical analysis}

Statistical analyses for biodiversity calculations were carried out by R 3.5.2 (Team 2019). One-way analysis of variance (ANOVA) was carried out to test the effect of tissue type (stem and leaf) on the colonization rate and species richness of endophytic fungi. Post hoc Tukey's Honest Significant Difference tests were performed to observe the significant differences among the tissue types at $\mathrm{P}<0.05$ level.

\section{Results}

\section{Investigation of endophytic fungi isolated from A. asi- atica}

In our study, 82 fungal endophytes were isolated from the A. asiatica plants collected from the southern Hungarian areas and the strains were identified using molecular taxonomical tools (Table 1). The endophytic fungi distributed into 3 classes and 5 orders, where the members 
Vigneshwari et al.

Table 1. Endophytic fungi isolated in this study.

\begin{tabular}{|c|c|c|c|}
\hline Plant part & Species & Collection code & Genbank ID \\
\hline Leaf & Alternaria sp. & SZMC 27067 & MT879608 \\
\hline Leaf & Alternaria sp. & SZMC 27068 & МT879609 \\
\hline Leaf & Alternaria sp. & SZMC 27069 & МT879610 \\
\hline Leaf & Alternaria sp. & SZMC 27070 & МT879611 \\
\hline Leaf & Alternaria sp. & SZMC 27071 & MT879612 \\
\hline Leaf & Alternaria sp. & SZMC 27072 & MT879613 \\
\hline Leaf & Alternaria sp. & SZMC 27073 & MT879614 \\
\hline Leaf & Alternaria sp. & SZMC 27074 & МT879615 \\
\hline Leaf & Alternaria sp. & SZMC 27075 & MT879616 \\
\hline Stem & Aspergillus sp. & SZMC 27076 & MT994591 \\
\hline Stem & Aspergillus sp. & SZMC 27077 & MT994592 \\
\hline Leaf & Aspergillus sp. & SZMC 27078 & MT994593 \\
\hline Stem & Aspergillus sp. & SZMC 27079 & MT994594 \\
\hline Stem & Aspergillus sp. & SZMC 27080 & MT994595 \\
\hline Stem & Aspergillus sp. & SZMC 27081 & MT994596 \\
\hline Stem & Aspergillus sp. & SZMC 27082 & MT994597 \\
\hline Stem & Aspergillus sp. & SZMC 27083 & MT994598 \\
\hline Stem & Clonostachys sp. & SZMC 27084 & MT883288 \\
\hline Stem & Cladosporium sp. & SZMC 27085 & MT883289 \\
\hline Stem & Cladosporium sp. & SZMC 27086 & MT883290 \\
\hline Stem & Cladosporium sp. & SZMC 27087 & MT883291 \\
\hline Stem & Cladosporium sp. & SZMC 27088 & MT883292 \\
\hline Stem & Cladosporium sp. & SZMC 27089 & МT883293 \\
\hline Leaf & Penicillium sp. & SZMC 27090 & МT994617 \\
\hline Stem & Clonostachys sp. & SZMC 27091 & MT940229 \\
\hline Leaf & Clonostachys sp. & SZMC 27092 & MT940230 \\
\hline Leaf & Curvularia sp. & SZMC 27093 & MT994617 \\
\hline Leaf & Curvularia sp. & SZMC 27094 & MT994617 \\
\hline Leaf & Diaporthe sp. & SZMC 27095 & МT940231 \\
\hline Leaf & Diaporthe sp. & SZMC 27096 & MT940232 \\
\hline Leaf & Diaporthe sp. & SZMC 27097 & МT940233 \\
\hline Leaf & Didymella sp. & SZMC 27098 & MT940234 \\
\hline Leaf & Didymella sp. & SZMC 27099 & MT940235 \\
\hline Leaf & Didymella sp. & SZMC 27100 & MT940236 \\
\hline Leaf & Didymella sp. & SZMC 27101 & MT940237 \\
\hline Leaf & Didymella sp. & SZMC 27102 & MT940238 \\
\hline Leaf & Didymella sp. & SZMC 27103 & MT994617 \\
\hline Stem & Alternaria sp. & SZMC 27104 & MT997192 \\
\hline Stem & Alternaria sp. & SZMC 27105 & МT997193 \\
\hline Stem & Fusarium sp. & SZMC 27106 & МT997194 \\
\hline Leaf & Fusarium sp. & SZMC 27108 & MT997196 \\
\hline Leaf & Fusarium sp. & SZMC 27109 & МT997197 \\
\hline Leaf & Fusarium sp. & SZMC 27110 & МT997198 \\
\hline Stem & Fusarium sp. & SZMC 27111 & MT881636 \\
\hline Stem & Fusarium sp. & SZMC 27112 & MT881637 \\
\hline Leaf & Fusarium sp. & SZMC 27113 & MT881638 \\
\hline Stem & Fusarium sp. & SZMC 27114 & MT881639 \\
\hline Leaf & Fusarium sp. & SZMC 27115 & MT997199 \\
\hline Leaf & Penicillium sp. & SZMC 27116 & MT997200 \\
\hline Leaf & Penicillium sp. & SZMC 27117 & МT997201 \\
\hline
\end{tabular}


Table 1. Continued.

\begin{tabular}{|c|c|c|c|}
\hline Plant part & Species & Collection code & Genbank ID \\
\hline Leaf & Penicillum sp. & SZMC 27118 & MT997202 \\
\hline Leaf & Penicillum sp. & SZMC 27119 & MT994761 \\
\hline Leaf & Penicillum sp. & SZMC 27120 & MT994762 \\
\hline Stem & Penicillum sp. & SZMC 27121 & MT994763 \\
\hline Leaf & Penicillum sp. & SZMC 27122 & MT994764 \\
\hline Leaf & Penicillum sp. & SZMC 27123 & MT994765 \\
\hline Leaf & Phomopsis sp. & SZMC 27124 & MT994766 \\
\hline Leaf & Phoma sp. & SZMC 27125 & MT994650 \\
\hline Leaf & Phoma sp. & SZMC 27126 & MT994651 \\
\hline Leaf & Phomopsis sp. & SZMC 27127 & MT994652 \\
\hline Stem & Phomopsis sp. & SZMC 27128 & MT994653 \\
\hline Leaf & Microsphaeropsis sp. & SZMC 27129 & MT994654 \\
\hline Leaf & Simplicillium sp. & SZMC 27130 & MT994655 \\
\hline Stem & Stemphylium sp. & SZMC 27131 & MT994656 \\
\hline Stem & Trichoderma sp. & SZMC 27132 & МT881591 \\
\hline Stem & Trichoderma sp. & SZMC 27133 & MT881592 \\
\hline Stem & Trichoderma sp. & SZMC 27134 & MT994657 \\
\hline Stem & Trichoderma sp. & SZMC 27135 & MT881593 \\
\hline Stem & Trichoderma sp. & SZMC 27136 & MT881594 \\
\hline Stem & Trichoderma sp. & SZMC 27137 & MT881595 \\
\hline Stem & Trichoderma sp. & SZMC 27138 & МT881596 \\
\hline Leaf & Trichoderma sp. & SZMC 27139 & MT881597 \\
\hline Stem & Trichoderma sp. & SZMC 27140 & MT881598 \\
\hline Stem & Trichoderma sp. & SZMC 27141 & MT881599 \\
\hline Stem & Trichoderma sp. & SZMC 27142 & MT881600 \\
\hline Stem & Phoma sp. & SZMC 27143 & MT994658 \\
\hline Stem & Phoma sp. & SZMC 27144 & MT994659 \\
\hline Stem & Phoma sp. & SZMC 27145 & MT994660 \\
\hline Stem & Microsphaeropsis sp. & SZMC 27146 & MT994661 \\
\hline Stem & Fusarium sp. & SZMC 27147 & MT994662 \\
\hline Stem & Fusarium sp. & SZMC 27148 & MT994661 \\
\hline
\end{tabular}

of Sordariomycetes were the most abundant (Fig. 1).

The isolation rate was recorded as 0.66 for leaf and 0.63 for stem and isolated fungi belong to 15 different genera. To characterize the biodiversity of endophytic fungi in the $A$. asiatica, the Shannon diversity index $\left(H^{\prime}\right)$ Simpson's diversity index (1-D), and Margalef's richness $(D \mathrm{mg})$ have been calculated. The Shannon-index revealed higher certainty of endophytic fungal species consistency in the stem compared to the leaf. Moreover, the Simpson's-index clearly showed that the stem harbored slightly diverse fungal endophytes compared to the leaf. Finally, based on Margalef's-index the stems have higher taxonomic richness than the leaf in A. asiatica (Table 2). Although the number of fungi in the leaves was higher than those in the stems, the notable difference was comparatively low (Fig. 2).

Strains belonging to Alternaria, Clonostachys, Didymella,
Fusarium, Microsphaeropsis and Penicillium, Phoma genera were isolated both from stem and leaves. However, the members of Curvularia, Simplicillium and Phomopsis genera were found only in leaves, while Aspergillus, Stemphylium. and Trichoderma were isolated only from the stem (Fig. 2, Table 1). These genera could be even tissue specific in A. asiatica, but to clarify this statement larger sample set would be favorable. It should also be considered that the host specificity of endophytic fungi can change the prevalence of their taxa in a particular plant and the divergence in the endophytic fungal community might be harbored in specific host tissues due to the histological difference and nutritional availability (Arnold et al. 2007).

\section{Antimicrobial effects of fungal extracts of $A$. asiatica endophytes}

Altogether, 328 extracts were tested against four bacte- 
Vigneshwari et al.

Table 2. Biodiversity parameters of endophytic fungi isolated from A. asiatica.

\begin{tabular}{llll}
\hline Diversity index & Stem & Leaves & Total \\
\hline Simpson's (1-D) & 0.1 & 0.13 & 0.07 \\
Shannon $\left(\mathrm{H}^{\prime}\right)$ & 2.62 & 2.36 & 2.96 \\
Pielou's evenness (J) & 0.89 & 0.87 & 0.9 \\
Margeref richness & 4.72 & 3.82 & 5.86 \\
\hline
\end{tabular}

ria, two yeasts and two filamentous fungi (Fig. 3, Fig. 4, Table 3). Our results revealed that altogether, 54 hexane, 78 ethyl acetate, and 73 chloroform extracts of the ferment broth and 78 mycelial extracts were active against at least one test strain. Remarkably high number of extracts (53) were active against B. subtilis, and $50 \%$ of the extracts were active against $S$. aureus (Fig. 2). However, lower percentage of extracts were active against Gramnegative bacteria including E. coli (31\%) and P. aeruginosa (28\%). The extracts of Didymella sp. SZMC 27102 strain exhibited high activity against all of the tested bacteria and yeasts, while the extracts of Phoma sp. SZMC 27125 and SZMC 27126 showed a remarkable activity against Gram-positive bacteria and the mycelial extract of these endophytic fungi showed high activity against Gramnegative bacteria. However, their extracts did not show any activity against yeasts and filamentous fungi (Table 3). Most of the Fusarium extracts exhibited remarkable antimicrobial activities against yeasts, but none of them were active against the two tested filamentous fungal strains. The ethyl acetate extracts of two Aspergillus isolates (SZMC 27077, SZMC 27078) showed a significant inhibitory activity (>90\%) against $B$. subtilis, $S$. aureus, $P$. aeruginosa and C. albicans.

During the yeast inhibition testing, C. krusei was found to be more resistant against the extracts than C. albicans (Fig. 3). In total, extracts of 46 strains were found to be possessing more than $90 \%$ inhibition against at least one test pathogen (Fig. 3). Taxa wise, Aspergillus, Alternaria, Fusarium and Didymella were found to have metabolites with effective yeast inhibition activity. Moreover, chloroform and mycelial extracts of Trichoderma isolates were mainly active against $R$. solani and F. culmorum (Table 3 ).

\section{Discussion}

Despite the biotechnological potential of endophytic fungi, the basic ecology about their relationship with the host plants is poorly understood. Furthermore, given the high biodiversity of plants in Hungary, examining their fungal endophytes could lead to the discovery of novel metabolites. Therefore, in our study the fungal endophytic community of $A$. asiatica was examined. The culturable endophytic fungi were identified using molecular techniques and their biodiversity, richness and tissue specificity were described. As these microorganisms have been generally identified as an abundant reservoir of novel antimicrobial compounds, the antimicrobial (i.e., antibacterial and antifungal) activities of the metabolites produced by the isolated fungi were also studied.

The fungi isolated from A. asiatica were characterized into 3 classes and 5 orders. All of the isolated fungi belonged to the phylum Ascomycota, which includes three classes, Dothideomycetes, Sordariomycetes and Eurotiomycetes. Our findings revealed that the leaves and stem parts of the $A$. asiatica are excellent reservoirs for endophytic fungi, where the most abundant genera were Fusarium, Trichoderma, Penicillium and Alternaria. Although Alternaria and Fusarium species are considered as plant pathogens, they might be latent when they are inside the living tissues until the environmental conditions are favourable and certain strains of them might have evolved to endophytic lifestyle due to loss of virulence (Freeman and Rodrigues 1993). These species are gaining a lot of attention recently for their bioactive

Table 3. Table 3. List of the endophytic fungi extracts showing inhibitory activities against plant pathogenic fungi.

\begin{tabular}{|c|c|c|c|c|c|c|c|c|}
\hline \multirow{2}{*}{ Strain code } & \multicolumn{4}{|c|}{ F. culmorum } & \multicolumn{4}{|c|}{ R. solani } \\
\hline & HEX & CLF & EtOAc & $\mathrm{C}: \mathrm{M}$ & HEX & CLF & EtOAc & $\mathrm{C}: \mathrm{M}$ \\
\hline SZMC 27132 & - & - & - & - & - & + & - & ++ \\
\hline SZMC 27133 & - & - & - & - & - & - & - & + \\
\hline SZMC 27134 & - & - & - & - & - & + & - & + \\
\hline SZMC 27135 & - & - & - & - & - & - & - & + \\
\hline SZMC 27136 & - & - & + & - & - & - & - & + \\
\hline SZMC 27137 & - & - & - & + & - & - & - & ++ \\
\hline SZMC 27138 & - & - & - & + & - & - & - & - \\
\hline SZMC 27141 & - & - & - & - & - & + & - & +++ \\
\hline
\end{tabular}




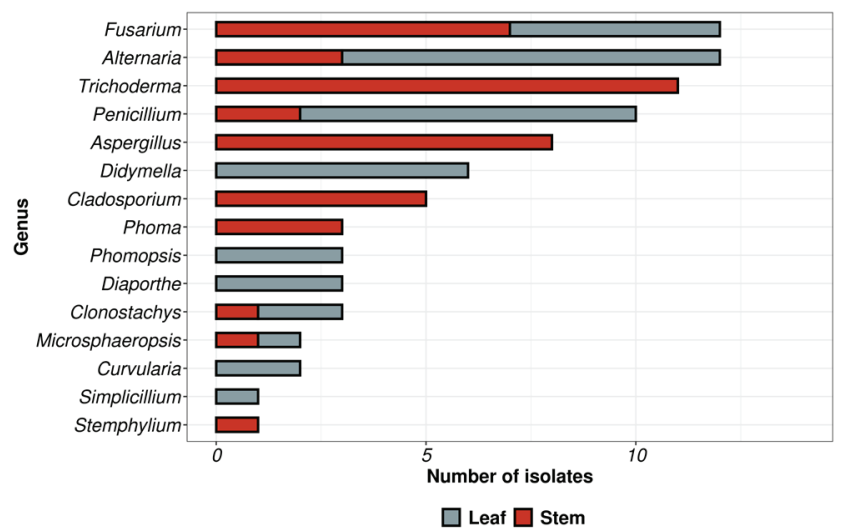

Figure 2. Distribution of endophytic fungi of $A$. asiatica at genus level.

compounds (Toghueo et al. 2019; Hellwig et al. 2002; Kaushik et al. 2020). Members of the Trichoderma genus were also found dominant in our study colonizing only the stems. In the literature, most of the studies reported the tissue specificity of Trichoderma species to roots and leaves (Rosemana et al. 2018). In addition, the colonization mechanism of Trichoderma sp. was also reported through systemic infection, which proved that the fungus could be re-isolated from stems rather than leaves and roots after the infection of roots (Rosemana et al. 2018).

In this work, five Phoma strains were isolated from stem and leaf. This genus is ubiquitous and inhabits a diverse range of hosts, from soil to air or from plants to animals (Aveskamp et al. 2010). Previously, extensive studies were carried out to clarify the significant generic boundaries in Didymellaceae, however, due to the lack of phylogenetic support of nearly 70 Phoma species belonging to Didymellaceae could not be assigned to definite genera (Aveskamp et al. 2010; Gruyter et al. 2013; Chen et al. 2017).

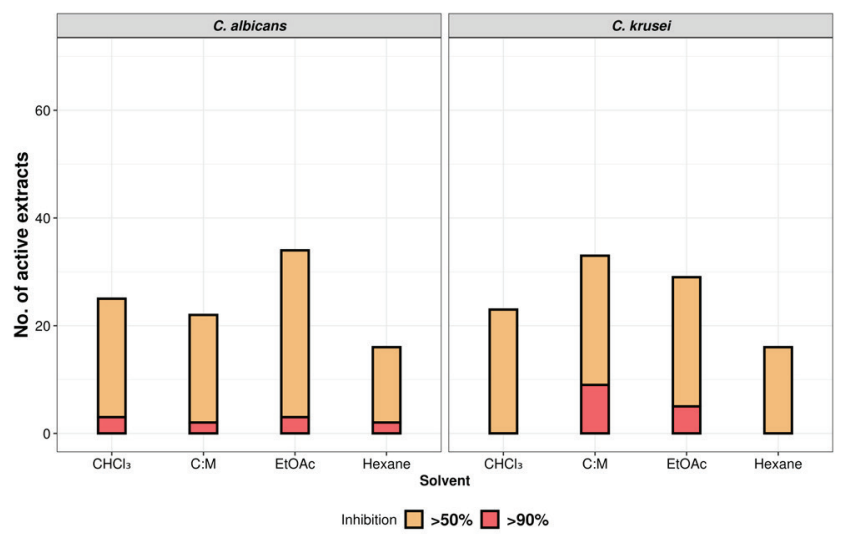

Fig. 4. Summary of the antifungal effects of endophytic extracts isolated from A. asiatica. $\mathrm{C}: \mathrm{M}$ = chloroform:methanol (4:1 V/V) extract of mycelia.

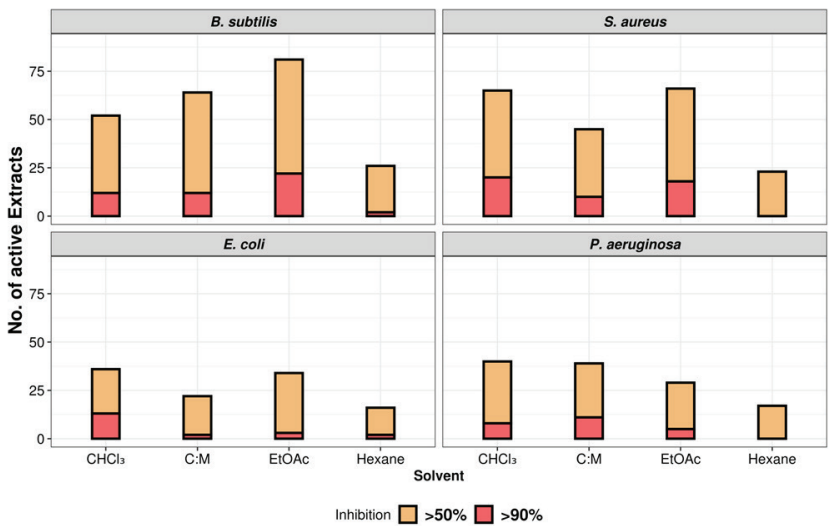

Figure 3. Summary of the antibacterial effects of endophytic extracts isolated from $A$. asiatica. C:M = chloroform:methanol (4:1 V/V) extract of mycelia.

In our cases, the isolation rate of the fungi were found to be the highest in stem, followed by leaf, whereas similar studies in other plants showed higher isolation rates in the leaf compared to stems (Alurappa and Chowdappa 2018). The tissue specificity are also affected by different environmental conditions. Previous studies showed that certain fungi, such as Aspergillus (El-Hawary et al. 2020) and Penicillium (Devi et al. 2012) species, did not exhibit tissue specificity. However, in our study, the Aspergillus strains were isolated only from stem.

Recently, an intensive research is required for effective antimicrobial drugs and the endophytic fungi are potential sources of these metabolites because they have been identified as an abundant reservoir of novel antimicrobial compounds (Strobel 2003). In the present work, 82 endophytic strains were isolated from the plant parts and the antimicrobial activity of their metabolites was evaluated. Altogether, $14.63 \%$ of the isolates had antibacterial effects with wide spectrum. Gram-positive bacteria were found to be more susceptible than Gram-negative bacteria and the observed antibacterial activity was higher than the antifungal activity. Altogether, $86.2 \%$ of the extracts were active against bacteria, whereas only $53 \%$ were active against yeasts and regarding Gram-positive bacteria, especially B. subtilis showed the highest sensitivity to the extracts. Alternaria and Aspergillus were the most predominant genera found to be exhibiting higher antibacterial activity than other fungi. Six out of 9 Alternaria strains had inhibitory activity against all the test organisms and at least one extract of all the Aspergillus isolates were active against all the test organisms. Furthermore, three and seven isolates showed inhibitory effects against the filamentous fungi F. culmorum and $R$. solani, respectively. 


\section{Acknowledgments}

This work was supported by the Hungarian Government and the European Union within the frames of the Széchenyi 2020 Programme, through grant GINOP-2.3.2-15-2016-00012. The relating research group was also supported by the grant OTKA K-128659 from the Hungarian Scientific Research Fund providing infrastructure and research equipment.

\section{References}

Ahuja A, Yi Y-S, Kim M-Y, Cho JY (2018) Ethnopharmacological properties of Artemisia asiatica: A comprehensive review. J Ethnopharmacol 220:117-128.

Alurappa R, Chowdappa S (2018) Antimicrobial activity and phytochemical analysis of endophytic fungal extracts isolated from ethno-pharmaceutical plant Rauwolfia tetraphylla L. J Pure Appl Microbiol 12:317-332.

Aveskamp MM, de Gruyter J, Woudenberg JHC, Verkley GJM, Crous PW (2010) Highlights of the Didymellaceae: A polyphasic approach to characterise Phoma and related pleosporalean genera. Stud Mycol 65:1-60.

Chen Q, Hou LW, Duan WJ, Crous PW, Cai L (2017) Didymellaceae revisited. Stud Mycol 87:105-159.

Cragg GM, Newman DJ (2013) Natural products: a continuing source of novel drug leads. Biochim Biophys Acta 1830:3670-3695.

Demain AL, Sanchez S (2009) Microbial drug discovery: 80 years of progress. J Antibiot 62:5-16.

Devi NN, Prabakaran JJ, Wahab F (2012) Phytochemical analysis and enzyme analysis of endophytic fungi from Centella asiatica. Asian Pac J Trop Biomed 2:S1280-S1284.

El-Hawary SS, Moawad AS, Bahr HS, Abdelmohsen UR, Mohammed R (2020) Natural product diversity from the endophytic fungi of the genus Aspergillus. RSC Adv 10:22058-22079.

Freeman S, Rodriguez RJ (1993) Genetic conversion of a fungal plant pathogen to a nonpathogenic, endophytic mutualist. Science 260:75-78.

Garyali S, Kumar A, Reddy MS (2013) Taxol production by an endophytic fungus, Fusarium redolens, isolated from Himalayan yew. J Microbiol Biotechnol 23:1372-1380.

Gruyter J, Woudenberg JHC, Aveskamp MM, Verkley GJM, Groenewald JZ, Crous PW (2013) Redisposition of phoma-like anamorphs in Pleosporales. Stud Mycol 75:1-36.

Hajdú Z, Martins A, Orbán-Gyapai O, Forgo P, Jedlinszki N, Máthé I, Hohmann J (2014) Xanthine oxidase-inhibitory activity and antioxidant properties of the methanol extract and flavonoids of Artemisia asiatica. Rec Nat Prod 8:299-302.

Hellwig V, Grothe T, Mayer-Bartschmid A, Endermann R,
Geschke F-U, Henkel T, Stadler M (2002) Altersetin, a new antibiotic from cultures of endophytic Alternaria spp. taxonomy, fermentation, isolation, structure elucidation and biological activities. J Antibiot 55:881-892.

Hoffman M, Gunatilaka M, Ong J, Shimabukuro M, Arnold AE (2008) Molecular analysis reveals a distinctive fungal endophyte community associated with foliage of montane oaks in Southeastern Arizona. J Arizona-Nevada Acad Sci 40:91-100.

Huang W-Y, Cai Y-Z, Xing J, Corke H, Sun M (2007) A potential antioxidant resource: Endophytic fungi from medicinal plants. Econ Bot 61:14.

Jalgaonwala RE, Mohite BV, Mahajan RT (2011) Natural products from plant associated endophytic fungi. J Microbiol Biotechnol Res 1:21-32.

Kaul S, Gupta S, Ahmed M, Dhar MK (2012) Endophytic fungi from medicinal plants: a treasure hunt for bioactive metabolites. Phytochem Rev 11:487-505.

Kaushik N, Díaz CE, Chhipa H, Julio LF, Andrés MF, González-Coloma A (2020) Chemical composition of an aphid antifeedant extract from an endophytic fungus, Trichoderma sp. EFI671. Microorganisms 8:420.

Khan AL, Gilani SA, Waqas M, Al-Hosni K, Al-Khiziri S, Kim YH, Ali L, Kang SM, Asaf S, Shahzad R, Hussain J, Lee IJ, Al-Harrasi A (2017) Endophytes from medicinal plants and their potential for producing indole acetic acid, improving seed germination and mitigating oxidative stress. J Zhejiang Univ Sci B 18:125-137.

Koul B, Taak P (2018) The Artemisia genus: A review on traditional uses, phytochemical constituents, pharmacological properties and germplasm conservation. J Glycomics Lipidomics 07:1-2.

Kumar S, Hyde K (2004) Biodiversity and tissue-recurrence of endophytic fungi in Tripterygium wilfordii. Fungal Divers 17:69-90.

Kusari S, Hertweck C, Spiteller M (2012) Chemical ecology of endophytic fungi: origins of secondary metabolites. Chem Biol 19:792-798.

Lam KS (2007) New aspects of natural products in drug discovery. Trends Microbiol 15:279-289.

Liu CH, Zou WX, Lu H, Tan RX (2001) Antifungal activity of Artemisia annua endophyte cultures against phytopathogenic fungi. J Biotechnol 88:277-282.

Newman DJ, Cragg GM (2016) Natural products as sources of new drugs from 1981 to 2014.J Nat Prod 79:629-661.

Oh TY (2005) Increased susceptibility of ethanol-treated gastric mucosa to naproxen and its inhibition by DA9601, an Artemisia asiatica extract. World J Gastroenterol 11:7450-7456.

Rosmana A, Sjam S, Asman A, Jayanti NJ, Satriana S, Padang AT, Hakkar AA (2018) Systemic deployment of Trichoderma asperellum in theobroma cacao regulates co-occurring dominant fungal endophytes colonization. J Pure Appl 
Microbiol 12:1071-1084.

Ryu BK, Ahn BO, Oh TY, Kim SH, Kim WB, Lee EB (1998) Studies on protective effect of DA-9601, Artemisia asiatica extract, on acetaminophen- and CCI4-induced liver damage in rats. Arch Pharm Res 21:508-513.

Sarker SD, Nahar L (2012) An introduction to natural products isolation. Methods Mol Biol 864:1-25.

Shukla S, Habbu P, Kulkarni VH, Jagadish K, Pandey A, Sutariya V (2014) Endophytic microbes: A novel source for biologically/pharmacologically active secondary metabolites. Asian J Pharmacol Toxicol 02:1-16.

Strobel G, Daisy B (2003) Bioprospecting for microbial endophytes and their natural products. Microbiol Mol Biol Rev 67:491-502.

Suryanarayanand TS, Kumaresan V (2000) Endophytic fungi of some halophytes from an estuarine mangrove forest. Mycol Res 104:1465-1467.

Talebi Bezmin Abadi A, Rizvanov AA, Haertlé T, Blatt NL (2019) World Health Organization report: Current crisis of antibiotic resistance. BioNanoSci 9:778-788.

Team RC (2019) R: A language and environment for statistical computing. R Foundation for Statistical Computing, Vienna, Austria. URL https://www.R-project.org/.

Toghueo RMK (2019) Bioprospecting endophytic fungi from Fusarium genus as sources of bioactive metabolites. Mycology 11:1-21.

Turbat A, Rakk D, Vigneshwari A, Kocsubé S, Thu H, Szepesi Á, Bakacsy L, D. Škrbić B, Jigjiddorj E-A, Vágvölgyi C, Szekeres A (2020) Characterization of the plant growthpromoting activities of endophytic fungi isolated from Sophora flavescens. Microorganisms 8:683.

Vigneshwari A, Rakk D, Németh A, Kocsubé S, Kiss N, Csupor D, Papp T, Škrbić B, Vágvölgyi C, Szekeres A (2019) Host metabolite producing endophytic fungi isolated from Hypericum perforatum. PLoS One 14:e0217060.
Wani K, Saboo S, Solanke P, Tidke P (2016) Production of novel secondary metabolites from endophytic fungi by using fermentation process. Indo Am J Pharm Res 6:4957-4961.

Weathers PJ, Arsenault PR, Covello PS, McMickle A, Teoh KH, Reed DW (2011) Artemisinin production in Artemisia апnиа: studies in planta and results of a novel delivery method for treating malaria and other neglected diseases. Phytochem Rev 10:173-183.

Weinstein MP (2018) Methods for dilution antimicrobial susceptibility tests for bacteria that grow aerobically, 11th ed. Clinical and Laboratory Standards Institute. Wayne, PA, USA.

White TJ, Bruns T, Lee S, Taylor J (1990) Amplification and direct sequencing of fungal ribosomal RNA genes for phylogenetics. In Innis MA, Gelfand DH, Shinsky JJ, White TJ, Eds., PCR Protocols: A Guide to Methods and Applications. Academic Press, San Diego, 315-322.

Yo HS, Ting ASY (2017) In vitro endophyte-host plant interaction study to hypothetically describe endophyte survival and antifungal activities in planta. Acta Biol Szeged 61(1):1-11.

Zhang H-W, Ying C, Tang Y-F (2014) Four ardeemin analogs from endophytic Aspergillus fumigatus SPS-02 and their reversal effects on multidrug-resistant tumor cells. Chem Biodivers 11:85-91.

Zhao J, Zhou L, Wang J, Shan T, Lingyun Z, Liu X, Gao L (2010) Endophytic fungi for producing bioactive compounds originally from their host plants. In MéndezVilas A, Ed., Current Research, Technology and Education Topics in Applied Microbiology and Microbial Biotechnology. Formatex Research Center, Spain, 567-576. 
